Revue d'études américaines. American Studies Journal

$2 \mid 2017$

(Hi)stories of American Women: Writings and Rewritings / Call and Answer: Dialoguing the American West in France

\title{
Martine Beugnet, Allan Cameron and Arild Fetveit, eds., Indefinite Visions: Cinema and the Attractions of Uncertainty
}

\section{David Roche}

\section{(2) OpenEdition}

\section{Journals}

Electronic version

URL: https://journals.openedition.org/transatlantica/10533

DOI: 10.4000/transatlantica.10533

ISSN: 1765-2766

Publisher

Association française d'Etudes Américaines (AFEA)

\section{Electronic reference}

David Roche, "Martine Beugnet, Allan Cameron and Arild Fetveit, eds., Indefinite Visions: Cinema and the Attractions of Uncertainty", Transatlantica [Online], 2 | 2017, Online since 19 April 2019, connection on 01 February 2023. URL: http://journals.openedition.org/transatlantica/10533 ; DOI: https://doi.org/ 10.4000/transatlantica.10533

This text was automatically generated on 1 February 2023.

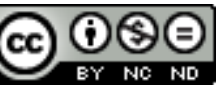

Creative Commons - Attribution-NonCommercial-NoDerivatives 4.0 International - CC BY-NC-ND 4.0 https://creativecommons.org/licenses/by-nc-nd/4.0/ 


\title{
Martine Beugnet, Allan Cameron and Arild Fetveit, eds., Indefinite
} Visions: Cinema and the Attractions of

\section{Uncertainty}

\author{
David Roche
}

\section{REFERENCES}

Martine Beugnet, Allan Cameron and Arild Fetveit, eds., Indefinite Visions: Cinema and the Attractions of Uncertainty, Edinburgh: Edinburgh University Press, 2018, 363 pages. ISBN 978-1474407144 (paperback), £ 24,99

1 Indefinite Visions, as Martine Beugnet's introduction makes clear, proposes to explore the presence and persistence of the indefinite in a medium that was invented to reproduce reality visually and study it. The book's project thus ties in with Vilém Flusser's (2004) view of the history of cinema as both a quest for legibility and an exploration of the obscure (9), evinced in Étienne-Jules Marey's 1891 study of a wave, La Vague. The collected volume comprises an introduction, nineteen chapters distributed into six sections and a very useful index. Each section is devoted to a specific modality of the filmic indefinite: illuminations, definitions, frames, temporalities, materialities and glitches.

2 The first part opens with Jacques Aumont's "The Veiled Image: The Luminous Formless." In it, Aumont examines a variety of cinematic veils (lens flares, chemical effects such as nitrate decay) that can reveal the intrusion of the cinematographer or of contingency, and raise questions about what an image can show; the figure of the veil is thus intimately connected to the ontology of the medium, since it can both assert its indexicality and reveal its artificiality. "The Black Screen" by Richard Misek starts with an overview of the device's functions (to conceal, to link, etc.) before moving on to the 
distinction between blackness and darkness, and black and white screens; he concludes that, if the black screen is meant to "signify nothing," "the presentation of nothing" is more dubious, except, perhaps, in digital media. The section concludes with Tom Gunning's "Flicker and Shutter: Exploring Cinema's Shuddering Shadow," which takes the flicker of early cinema as proof of the importance of not seeing since the birth of cinema, even though technology aimed to eliminate it; avant-garde directors like Peter Kubelka, Paul Sharits and Tony Conard later sought to explore the sensual potential of flicker.

In the second section, Erika Balsom's "One Hundred Years of Low Definition" insists that it is necessary to distinguish between image resolution as "a matter of quantity" and "definition as a means of describing the degree of detail visible to the viewer, a matter of quality" (73), before concluding that definition "is thus best understood not as a stable technological capacity but as a relationship to the viewer that is distinguished by the degree of perceptual detail available within any given image" (74); she then traces a history of the "theory of the function and appeal of low-definition of images" in the writings of Ricciotto Canudo and Rudolf Arnheim, where low-definition was seen as a means for cinema to abandon the facile reproduction of photography, and veer towards painting and thus art. In "Genres of Blur," Martin Jay's interest in visual blurs leads him to posit the blur as a hermeneutic principle of inquiry that ideally combines two focal points. Finally, Giusy Pisano's "In Praise of the Sound Dissolve: Evanescences, Uncertainties, Fusions, Resonances" recalls that sound design as an aesthetic model dates back to the 1930s and underlines the pitfalls of much writing on film sound, which relies too much on binary categories (offscree/onscreen, diegetic/ nondiegetic music) disproved by practice; she ultimately calls for an approach to sound as "the mise en scène of a continuum through which it resonates with images" (116).

The third section starts with Michel Chion's "Jumps in Scale," a brief reflection on extreme variations in shot sizes mostly in contemporary cinema, with 3D adding the apprehension of volume. Julian Hanrich's "Reflecting on Reflections: Cinema's Complex Mirror Shots" then proposes a compelling typology of what he calls complex mirror shots, i.e., "shots in which characters and other salient sources of attention are reflected in the mirror but remain beyond the screen frame" (131), with examples taken mostly from art cinema (Dreyer, Duras, Fassbinder, Resnais, Sirk); he argues that such shots are doubly reflexive, making us "conscious of one's act of looking and of the medium itself" (152). Christa Blümlinger's "Cinematographic Indeterminacy According to Peter Tscherkassky: Coming Attractions" is a case study of the 2010 found footage film, whose aesthetics of collage criticizes "a teleological vision of film history" and offers instead what Tscherkassky calls a "non-intentional cinema," which Blümlinger describes as "a sort of intensive practice of degrees of indetermination or of indefinition which is the basis of all figurative dynamics" (176). In "Partying in The Great Gatsby: Baz Luhrmann's Audiovisual Sublime," Carol Vernalis proposes a case study of the party sequence, whose aesthetics challenges traditional film analysis and leads Vernalis to attempt to circumscribe it by identifying nineteen strategies, of which, she admits, it is difficult to gauge the combined effect,

The fourth section opens with "The Force of Small Gestures," D.N. Rodowick's discussion of Bergson's theory of time and Deleuze's Francis Bacon: The Logic of Sensation, illustrated mainly with Ernie Gehr's Glider (2001); in order to create the conditions of the emergence of the Figure, a focal point that is not separate from the other orders of 
sensation (the material structure, the contour) (217), "experimental film and video" can resort to "random movements of hand and body, and to sometimes recording without active and attentive framing" (220). Kriss Ravetto-Biagoli's "Bill Viola and the Cinema of Indefinite Bodily Experience," a case study of The Passions series (2001), raises insightful theoretical questions on the relation between technology and figures and their uncertain status by means of the uncanny as reconceptualized by cognitive scientists; Viola's work demonstrates that the "emotive gesture" is already "iconic," "a mechanical bodily expression rather than an intense emotional one," and thus that "[t]he return of an embodied perception is itself uncanny: the body only registers the reflection of a gesture when it returns in the form of a ghostly image" (237). In "Slow Looking: Confronting Moving Images with Georges Didi-Huberman," Catherine Fowler demonstrates how Sharon Lockhart's Double Tide (2009) responds to the French theorist's call to "look and be open to 'not knowing"' (241), and that its slow aesthetics thus differs from the slow cinema tradition of Akerman, Tarkovski and Haneke, which tends to oppose seeing and thinking.

6 In the fifth section, Kim Knowles's "(Re)visionist Celluloid: Aesthetics of Contact in Materialist Film" traces the history of experimental cinema "as a history of unstable or indefinite vision," from a materialist perspective where the film is a record of its own making to a new materialist one for which the vulnerability of celluloid enables it to dialogue with the earth and participate in an environmental politics (in the works of David Gatten, Emmanuel Lefrant, Tomonari Nishikawa and Alia Syed). Emmanuelle André's "Seeing through the Fingertips" views Godard's Goodbye to Language (2014) as an exploration of leafing as a new way of seeing, foreshadowed in Nicolas Ray's last feature film, We Can't Go Home Again (1973), which resembles an atlas to be leafed through. Raymond Bellour's "Homo Animals Kino" touches on what happens when an animal presence penetrates a film in Holy Motors (Leos Carax, 2012), Leviathan (Lucien Castaing-Taylor and Véréna Paravel, 2013) and Goodbye to Language.

7 The final section opens with Sean Cubitt's “Temporalities of the Glitch: Déjà Vu." After definining "glitches as epiphenomena of the material and temporal substrate of electronic transmission" (300-1) and pinpointing its "liminality" as "operat[ing] between the smooth, insensible operation of numerical code and the eruption of code into sensation" (303-4), he foregrounds how, in Tony Scott's 2006 film, "the glitch acts as a marker of this threshold over which the contents of the past must be dragged to bring them back into present, the field of action"; ultimately, the glitch signifies a critical rupture in the digital flow of the market, a tear in the commodified image. In "The Glitch Dimension: Paranormal Activity and the Technologies of Vision," Steven Shaviro focuses on the Paranormal Activity franchise whose reliance on the glitch is, in a sense, the exploitation version of art gallery works, particularly in The Ghost Dimension (Gregory Plotkin, 2015), which demonstrates that "the real phantoms that are generated by the intrinsic limitations and inevitable breakdowns of these technologies" (330). Finally, Allan Cameron's "Facing the Glitch: Abstraction, Abjection and the Digital Image" analyzes the way glitch aesthetics disfigure the image in video and digital film; his compelling study reveals that "these multi-layered operations of the glitch work by unmasking (revealing the image's basis in code), effacement (showing its dependence on technical materiality), and in some cases facing (giving the image an identity and meaning, whether abject or otherwise)" (349). 
It is hard to imagine a more well-rounded-off collected volume than Indefinite Visions. With some of the major names in film studies, its table of contents asserts its ambition to make a notable contribution to the field of film aesthetics. Credit must also be given to the editors for uniting several generations of scholars; this, for me, is the book's strongest point, and the quality of the chapters written by younger scholars is proof that film aesthetics remains a flourishing field. The book's range is also impressive, with chapters dealing with avant-garde and experimental film and video (Balsom, Blümlinger, Cameron, Fowler, Gunning, Knowles, Ravetto-Biagoli, Rodowick), mainstream (Cubitt, Shaviro, Vernalis) and art cinema (André, Bellour, Hanrich), and often referring to both (Aumont, Chion, Misek). Most chapters, including the case studies, are very ambitious theoretically and resonate with many of the questions (the digital, haptic visuality, sound design) that have come to the fore since the 1990s; some (Balsom, Cameron, Cubitt, Gunning, Knowles, Ravetto-Biagoli) are quite simply brilliant. One could consider that the volume lacks a clear argument because of the theme itself, but this would be in bad faith given that the majority of the authors incorporate a discussion of the indefinite or the vague in their arguments. Reading some of the pieces on experimental film and video made me realize how complicated it was to approach these works methodologically speaking. Their high degree of conceptualization challenges the scholar, insofar as they seem to discourage analysis and call on theory to explain their inner workings; this can lead to the pitfall of imposing a theory on a given work, and thus on using the work to prove the theory right-or more basically, on overly relying on the artist's intentions. But apart from a very poorly translated opening chapter and two brief chapters that fail to make a point, Indefinite Visions is flawless academic research. More importantly, perhaps, it is engrossing, illuminating and mind-broadening, thanks to the attention paid to less well-known artists. It is required reading for any scholar of film and video aesthetics.

\section{BIBLIOGRAPHY}

Works Cited

DELEUZE, Gilles, Francis Bacon: The Logic of Sensation, translated by Daniel W. Smith, London and New York, Continuum, 2000 (๔ 1981).

DIDI-HUBERMAN, Georges, Images in Spite of All: Four Photographs from Auschwitz, translated by Shane B. Lillis, Chicago and London, University of Chicago Press, 2008 (๔ 2003).

FLUSSER, Vilém, Pour une philosophie de la photographie, Paris, Circé, 2004.

DE PARVILLE, Henri, “Le cinématographe," Les annales politiques et littéraires, April 26, 1896.

\section{INDEX}

Subjects: Recensions 
AUTHORS

DAVID ROCHE

Université Toulouse Jean Jaurès 